\title{
Differences in Children's Writing Develepment in The US and Turkey
}

\author{
D. Neslihan Bay (Corresponding author) \\ Faculty of Education, Eskisehir Osmangazi University \\ PO Box 26480, Meselik Campus, Odunpazarı, Eskisehir, Turkey \\ E-mail: bayneslihan@gmail.com
}

\author{
Ozlem Simsek Cetin \\ Faculty of Education, Kirıkkale University \\ PO Box 71450, Kırıkkale, Turkey \\ E-mail: ozlemsimsek@gazi.edu.tr
}

\author{
Douglas K. Hartman \\ College of Education, Michigan State University \\ PO Box 48824, East Lansing, MI, US \\ E-mail: dhartman@msu.edu
}

Received: Jan. 29, 2015 Accepted: March 11, 2015 Published: May 1, 2015

doi:10.5296/jse.v5i2.7160 URL: http://dx.doi.org/10.5296/jse.v5i2.7160

\begin{abstract}
The purpose of this study was to examine children's writing development in preschool classrooms in the US and Turkey. Three preschool teachers working in Turkey and one teacher working in the US were interviewed, and writing samples were collected from students in four classes. İn this study, four categories were identified: (1) teachers' literacy beliefs, (2) writing activity descriptions, (3) writing materials, and (4) writing samples. Each teacher was interviewed for approximately 25 minutes in a quiet setting at the preschool. Interview
\end{abstract}




\section{Macrothink}

questions were originated from studies by Lynch (2011) and Ure and Raban (2001), which were aboutpreschool literacy beliefs. All teachers' interviews were audio recorded and transcribed. Writing samples were collected from the children in the class. The classroom focus was on using writing materials, which were identified with a materials checklist. The writing activities were examined for one month in terms of the writing skills implemented. The preschool teacher in the US had a more structured approach about early writing development than the one in Turkey, and the children in the US, especially 3-year-old children, showed better writing skills than the children in Turkey. The results showed that there are more writing materials and activities in the US classes than the ones in Turkey's classes. Such differences may be attributed to differences in beliefs and knowledge about early literacy development, curricula, writing materials, and literacy perspectives, in two countries. The results of this study offer insights for the importance of early literacy development in preschool classrooms.

Keywords: Early literacy, Preschool, Reading, Writing, Curriculum, Writing material 


\section{Introduction}

Children have many emergent literacy skills before beginning school. There is much research that emphasizes emergent literacy skills, which develop from infancy through early childhood (Fogo, 2008). Before children are able to write conventionally, they possess a majority of the skills in these early years, that they will needlater. Therefore, how children's writing develops is a very important question (Puranik \& Lonigan, 2011). The emergent writing process has developmental steps by which children learn to write (Bakst \& Essa, 1990); Buxton, 2011). Also, early experiences with reading and writing have effects on children's writing development (Fogo, 2008). This development is called the emergent writing process, and ithas five stages: scribbling, drawing, writing letters, name writing, spelling, and conventional writing.

Children begin to write with a scribble-writing process, and they write using their hands, as a part of their gestures (Bakst \& Essa, 1990; Fogo, 2008). In other words, children begin to scribble in infancy, if they encounter writing opportunities. According to Puranik and Lonigan (2011), children's scribbles include universal features, such as linearity (writing units/marks), so that children's beginning writing contains all languages' common features. Scribble-writing resembles the features of printed writing, such as being linear, vertical, horizontal, and circular (Fogo, 2008). After children have many experiences with scribbling, they begin drawing as the next stage (Bakst \& Essa, 1990). This stage does not have letters or words (Puranik \& Lonigan, 2011). However, children's drawings or symbols do represent a communication method (Buxton, 2011). Early guidance for children encouranges their motivation to write, and when children are exposed to writing, they begin to understand many different signs and print (Buxton, 2011; Fogo, 2008). Therefore, children's early knowledge about writing plays a vital role for their later literacy success (Puranik \& Lonigan, 2011). Preschool teachers should encourage children's emergent writing with a rich environment, such as children's books and other print forms (Buxton, 2011). In this way children continue on to the next stage, called letter writing.

Children begin to write imitations of letters, and they often mix real letters and drawings, which is called mock writing (Bakst \& Essa, 1990). When children have experience with letter writing, they begin to acquire alphabet knowledge (Fogo, 2008). Children's letter writing ability increases, from age 3 to age 5 (Puranik \& Lonigan, 2011). Children's first writing is usually their own name (Buxton 2011; Fogo, 2008). Children's name writing emerges as a prototype of sequential writing in the early years (Levin, Both-De Vries, Aram, \& Bus, 2005). Writing awareness and letter awareness begin to improve with their own names (Bakst \& Essa, 1990). According to Haney (2002), name writing shows each child's development in literacy. Many 4- to 5- year old children can write their own name in conventional writing (Levin, et al., 2005). After children describe their names' letters, they identify other letters in the alphabet (Fogo, 2008). When children have experience with their own name writing, they gain letter knowledge (Levin, et al., 2005). Children begin to understand that meaningful writing is related to letter writing and reading success (Fogo, 2008). Therefore, children build sound-symbol relationships in terms of using their knowledge of the letters in their names (Haney, 2002; Levin, et al., 2005). Children's names are phonologically patterned in their 
language (Levin, et al., 2005). Children learn how sounds and symbols work together with their name writing skills, because name writing skills give the best prediction about basic reading skills (Haney, 2002). When children use name letters, they bond between the names' letters and the letters' sounds. Therefore, children need to be encouraged toward their name writing in preschool (Fogo, 2008). When preschool teachers support children's name writing, children gain more experience in writing letters (Fogo, 2008; Levin, et al., 2005). Preschool teachers should create activities for developing children's name writing with daily opportunities (Haney, 2002). Writing activities provide children with the time to explore the next stages, which is spelling.

Children continue their emergent writing process with spelling (Fogo, 2008). Spelling skills improve during three different stages. Children begin to combine letters and sounds with "Pre-phonemic Spelling," and then they use their current knowledge of vocabulary in spelling with "Phonemic Spelling." When children read without help, they begin the "Transitional Spelling" stage, during which they often spell the wrong word. The next stage is conventional spelling, such as adult writing (Buxton, 2011). Children do editing of their own writing in this stage (Bakst \& Essa, 1990). For children to be successful, teachers should observe their writing regularly. Children usually encounter problems in their writing, and they need help solving writing problems (Buxton, 2011). Therefore, preschool teachers should provide guidance for children. In this way, children can have more independent writing opportunities (Buxton, 2011). In the helping process, children can learn how to write conventionally with their teachers' support.

In summary, children's writing knowledge improves sequentially from simple to complex. Children begin first with scribbling, and their writing develops into specific writing features. Children gain much knowledge about the writing system in their early years, and their early writing development skills relate to their later literacy development (Puranik \& Lonigan, 2011). Early intervention is necessary to prevent children's failure in the following years (Haney, 2002). Therefore, preschool teachers should provide multiple opportunities and support with classroom activities for encouraging children's emergent writing skills. In this way, children explore writing features meaningfully (Fogo, 2008). In conclusion, because early children's writing skills affect their later literacy skills, supporting children is gaining vital important for their long term success.

\subsection{The purpose of The Study}

This study is to examine the development of children's writing in preschool in two countries: the USA and Turkey. We addressed this aim in four ways: The development of children's writing in both countries was explored in terms of a) children's writing samples, b) the preschool teachers' literacy beliefs, c) writing activity descriptions, and d) writing materials in the classrooms.

The process for this study included formulating categories based on the interviews, using writing samples from the children, and examining the preschool curriculum and writing materials in classrooms. 


\subsection{Significance of the Study}

The results of this study will enable the examination of the writing development of both of countries' children. Also, we identify what affects children's writing development, such as materials, teachers' beliefs, and curricula, because both countries have different applications about preschool education.

Children's writing experiences in using print materials in real contexts supports children's print awareness and permits children to build a conceptual structure about the purposes of printed materials (Purcell-Gates, 1996). They are able to draw from these experiences to infer more specific skills of the alphabetic code about learning writing (Clay, 1991, 2001). Preschools should provide writing materials for children to use independently and comfortably (Morrow, 2007).

Furthermore, teachers use their beliefs about how children can learn and what the important skills are for improving children's writing in their classroom practice (Parker \& Neuharth-Pritchett, 2006). Many preschool teachers do not have the opinion that literacy is a concern of the preschool curriculum (Lynch, 2009; Ure \& Raban, 2001). Teachers define broadly based literacy concepts; they do not actively encourage the support of literacy teaching through mediation with many examples (Fleer \& Raban, 2006). Ure and Raban (2001) have explained that preschool teachers do not have broad expectations for children's literacy development. Therefore, teachers do not know as to how to explicate literacy and how to translate knowledge and teaching strategies into literacy activities (Dickinson \& McCabe, 2001). It is important that teachers have a sense of children's needs about their developing writing, and support children's literacy and writing learning (Morrow, 2007).

Another factor is the preschool curricula, which support the development of early writing skills (Schickedanz, 1998), such as knowledge of environmental print (identifying print within the environment), notions of print (understanding that printed text is read from left to right and top to bottom of a page), letter or alphabet knowledge (recognition of letters), and letter-sound knowledge (understanding letters represent sounds) (Neuman, Copple, and Bredekamp, 2000). Teachers decide writing activities in terms of curriculum, and they can select objects according to their own proposes (Morrow, 2007). Many preschool teachers do not view literacy as central to the preschool curriculum (Fleer \& Raban, 2006).

Finally, the results of this study weredescribed by which factor shows differences in both countries. Therefore, this study show the effectiveness of all factors for developing children's writing.

\section{Method}

\subsection{Participants}

Preschool teachers and classrooms were randomly selected to participate in this study in the USA and Turkey. Four teacher interviews were conducted. Three preschool teachers located in Kirikkale in Turkey participated, and one multigrade preschool class teacher in East Lansing, MI, in the USA participated in the interviews, and the teachers' beliefs about practice 
were the focus of this study. It was requested that the participating teachers have an ECE (Early Childhood Education) diploma (generally a 4-year program) and be currently working with 3-, 4-, and 5-year-old children (preschool age). The participating preschool teachers in Turkey each had a four-year ECE diploma, and the preschool teacher in the US had an ECE masters degree. Also, the three- and four-year-old classroom preschool teachers in Turkey had four years of educational background, five-year-old class teacher had three years of educational background, and thefour, and five-year-old-classroom teacher in the US had 10 years educational background.

In the classes, children who received permission from their family participated in the writing samples activities, and their developments in writing were the focus of this study. Sixteen children (five children three-years-old, five children four-years-old, and six children five-years-old) participated from Turkey, and 11 children (three children three-years-old, four children four-years-old, and five children five-years-old) participated from the US. This study totally examined 27 writing samples of the children from both countries.

\subsection{Procedure}

\subsubsection{Interview}

Preschool teachers' beliefs about children's developmental literacy provide encouragement of children's emergent literacy with practice (Lynch, 2009). Therefore, one preschool teacher of combined a class teacher with children from three to five years old, was interviewed in the US and three preschool teachers with children three, four, and five years old class teachers were interviewed in Turkey about their literacy beliefs. Each participant was interviewed for approximately 25 minutes in a quiet setting at the preschool. The 16 questions asked originated from studies by Lynch (2011), and Ure and Raban (2001) about preschool literacy beliefs. All teachers' interviews were audio recorded and transcribed in their entirety by the researcher.

\subsubsection{Writing activity description}

Writing activities encourage children to improve their writing skills, and we examined writing activities for both countries. Therefore, the writing activities used by the participating teachers were identified inside four weeks to determine how many activities involved writing.

\subsubsection{Writing materials in the classrooms}

Because children are engaged in their writing skills, the classroom provides a rich print environment, with children's book and other print forms (Buxton, 2011). Using the materials in the classroom, we identified writing materials with a materials checklist constructed by the researcher. Using this checklist, we coded what materials were used by children for writing in the classrooms.

\subsubsection{Writing samples}

The writing tasks were broadly formulated. In this study, data collection was conducted on the writing activity of each child, by collecting writing samples in their classrooms. The teacher said in small group time, for instance, "Now, I want you to write letter to your mother." The 
children produced samples with white A4 paper, crayons, and color pencils, and some tools from their own pencil cases. Also, the teacher conducted a writing activity with the children for collecting writing samples in the classroom. The teachers routinely instructed them to put their name on the finished writing.

\subsection{Data analyses}

In this study we collected four different data types. The data was analyzed by examining the transcriptions of interviews, the writing samples, the implemented school curriculums, and the writing materials in the classrooms. First, interview data was organized into main categories, and the important elements of writing in preschool classrooms were highlighted. Second, the writing samples were scanned into a computer after each writing session, and then they were coded as to their developmental level according, to Sulzby's (1986) scheme for classifying the forms of writing. This theory exposes five levels of writing development: writing via drawing, writing via scribbling, writing via letter-like shapes, writing via letters or letter strings, and writing via conventional spelling. Higher level writing samples were chosen for each child from their writing samples. The children's writing samples were coded according to this developmental theory:

Writing via drawing: Children use drawings for writing their communication.

Writing via scribbling: Children use scribble-like writing, from left to right.

Writing via making letter-like shapes: Children's writing uses shapes like letters.

Writing via the letters or letter strings: Children use letters in different ways, as in long strings or in random order.

Writing via conventional spelling: Children write similar to adult writing (Morrow, 2007).

Third, the implemented preschool curriculum was exhibited in terms of writing skills for the participating preschool in both countries, and in each classroom the number of writing activities was determined inside one month. Fourth, writing materials identified in the classrooms with a material checklist. Finally, the collected data was combined for explaining the effectiveness of the various factors, and how this varied by nation, on children's writing skills.

\subsection{Inter-rater reliability}

The writing samples were coded by the two researchers and double-checked independently. To provide conformity in coding, $100 \%(n=27)$ of the writing samples were coded to acquire inter-rater reliability. Inter-rater reliability was calculated, and the reliability of coding for children's writing samples was $93.6 \%$.

\section{Findings}

Four categories were included in the data: interviews, writing activity descriptions, writing materials, and writing samples. 


\subsection{Interviews}

First, this study was showed teachers literacy beliefs interviewing four preschool teachers. The 16 Preschool Literacy Beliefs Interview Questions originated in studies by Lynch (2011) and Ure and Raban (2001). The preschool teacher in the US focused on each category to provide a more detailed description of literacy beliefs. The preschool teachers in Turkey represented a narrow range of their belief and practices. Pseudonyms were used for the teachers' names. Some information about their education programsis given in Table 1.

Table 1. Descriptions of Preschool Teachers

\begin{tabular}{|c|c|c|c|c|}
\hline Teachers & $\begin{array}{l}\text { Educational } \\
\text { Background }\end{array}$ & Seniority & $\begin{array}{l}\text { Typical half day at the } \\
\text { preschool }\end{array}$ & $\begin{array}{l}\text { Educational } \\
\text { Program }\end{array}$ \\
\hline $\begin{array}{l}\text { Nur (three years } \\
\text { old class teacher) }\end{array}$ & undergraduate & 4 & $\begin{array}{l}\text { Free choices, play, stories, } \\
\text { play, and music }\end{array}$ & $\begin{array}{l}\text { Using ready } \\
\text { program }\end{array}$ \\
\hline $\begin{array}{l}\text { Ipek (four years } \\
\text { old class teacher) }\end{array}$ & undergraduate & 4 & $\begin{array}{l}\text { Play, look science journals, } \\
\text { gym, music }\end{array}$ & $\begin{array}{l}\text { Using } \\
\text { prepared } \\
\text { program }\end{array}$ \\
\hline $\begin{array}{l}\text { Sevgi (five years } \\
\text { old class teacher) }\end{array}$ & pre-license & 3 & $\begin{array}{l}\text { Free choices, art, music, } \\
\text { literacy readiness, science, } \\
\text { and mathematics. }\end{array}$ & $\begin{array}{l}\text { Using } \\
\text { prepared } \\
\text { program }\end{array}$ \\
\hline $\begin{array}{l}\text { Linda (three, } \\
\text { four, and five } \\
\text { years old class } \\
\text { teacher) }\end{array}$ & masters degree & 10 & $\begin{array}{l}\text { Free choices, outside, read } \\
\text { a book, large group, small } \\
\text { group, free choices, large } \\
\text { group }\end{array}$ & $\begin{array}{l}\text { Using own } \\
\text { program }\end{array}$ \\
\hline
\end{tabular}

Looking at the daily activities, the preschool teachers in Turkey reported only activity names, while Linda broadly explained all her daily activities. For example, in the free choices times, Linda said, "All of the classroom is open; children can go art; they can go black area; pretend play; they can move freely, so it is not a structure time. They want to go blocks for 5 minutes, writing table for 2 minutes, so it is not teacher directed things they can go everywhere." Actually, the daily routine in the US does not have to be directly related to writing activity, but each activity is supportive of the writing. Linda explained supportive writing:"Literacy is all around the classroom, so in the block area have markers, pencils, papers, pretend play have many things. It is all around the classrooms. Not that just is in one specific area and literacy is a just thought at book look time, literacy is a just thought at large group area, it is all true out at curriculum."

In Turkey, the curriculum includes a directly writing preparation activity, like line work, hold a pencil, and pointing under the leadership of the teacher. However, the curriculum does not have any teaching of the letter of the alphabet for children tring to write.

Nur, İpek, and Sevgi used a prepared program to on the publishing company. Linda took a curriculum class, an assessment class, and a methods class in her master degree. Thus, she 
expressed that she knew about preparing a plan and she tried different ways and used more things. Otherwise, İpek said, “ My education in university is not enough for preparing program." Also, when we asked if they would like any changes about literacy in the ECE preparation program, Linda expressed that she knew the importance of literacy and the dependence of learning on visual experience. She also told that students who have more lore are able to understand the material faster than others. For this question, other teachers said that teaching with playing should be used more.

When we asked if they would like to know more about supporting literacy, while Nur did not need to know about supporting literacy for three-year-old children, İpek and Sevgi wanted to learn how teachers can support children's literacy with playing. On the other hand, Linda thought that she could support literacyin all of the activirties she learned from her program.

To another question, how important print literacy, Nur said "Not important for three years old", and İpek and Sevgi answered similarly. They said, "I don't teach writing, but I believe print literacy is important." However, Linda said, "Print literacy so important. The special for when they will learn for the first name because that is the personal to them. In that first, they will learn because they use all the time. They see all their name tech, they see when we talk about jobs they see their name; they see their name hanging up on the wall, because they did our projects, their name on projects, so seen print literacy all around the classroom is so important."

Similarly, while Linda thought that all activities involve improving literacy skills, the other teacher said that some activities, such as concept teaching and finger games, are related to literacy skills. We asked whether there are any children who know reading and writing in the group, and only Linda told that her group had. Linda said that she was organising activities that build writing awareness. She told that she was performing a restaurant activity in which the students were making orders by writing. She also said that after puppet shows, the students were trying to draw shapes and write about the show.

When we asked about the teacher's role for encouraging the reading and writing skills of children, Nur said "teaching concept," and İpek and Sevgi said, "Only guidance." However, Linda expressed an extensive answer: "I play is displayed, so I supply them the materials and I will show them at large group. I will show them in their small groups and then they will be able to explore. So I believe that the curriculum, we used true constant exploration and discovery children predicting. I things like that they can miniplay the materials and they can use them the way they think. They can be used and then I can say 'Oo, have you ever tried this. Displayer is what I was really I just give them materials and then I support their learning that way.' " On the support of parents, Nur said, "Reading story"; İpek and Sevgi said, "Parent involvement activities"; and Linda also said that constructing parent-teacher communication is important. Linda told that she was organising an activity where the students were collecting newspaper columns and pictures. After that, the students were having a discussion in the class on what they see for each collection. In addition, the students were bringing a list of things that they take from their parents. She said that she was performing such reading and writing activities to build writing awareness in children. She said that the writing activities both in the school and at home help build writing awareness. 
Furthermore, the teachers gave information about their preferred way to foster the reading and writing development of children. While Nur expressed that she offers line working and matched games, Sevgi and İpek said that they offer concepts and line work. Linda said that children should improve through five developments, such as social experiences, affective experiences, language experiences in the classroom environment and true out.

Finally, when we asked what age they encouraged to read and write, Nur said that it can begin in kindergarten. Sevgi and İpek said that it could begin at three-years old with concept work. However, Linda said that the earlier the parents read their children at home, the better the children would have learning experiences.

\subsection{Writing activity description}

Second, this study was focused on the teachers' writing activities within one month. In Turkey, children take a class separately, according to their ages, so we examined two class programs, the three- and four-year old class together and five-year old class; however, in the US all children get education in the same class, and they have one program. Children had 10 directly writing activities, such as drawing, painting, or writing, within the one month in the US. On the other hand, in Turkey the three- and four-year old children had five writing activities and the five-year old children had nine writing activities. Because early childhood education programs do not directly focus on writing in Turkey, programs do not include letter or word writing activities. Usually, the participating Turkish teachers conducted drawing a picture or drawing a line in their literacy preparation activities, but in the US, the teacher directly conducted writing activities, and the children wrote some letters and words in their language activities.

\subsection{Writing materials}

Third, this study examined classroom writing materials in each country's preschool classrooms. We composed a writing materials checklist that included two parts (print materials and writing materials) and 18 items, for classrooms. In the US, each item was coded as existing for the classroom, but in Turkey classrooms did not have some items. In Turkey, all classrooms center had very few writing materials, and the classrooms did not have a writing center. Print materials are necessary for the print awareness of children, such as children's name cards, alphabetposters, letter patterns, making boks by children, and center name cards, these were absent in classrooms in Turkey. However, the Turkish classrooms included different kinds of paper, different kinds of pencil, chalk and board markers, writing boards, a weather chart, and a calendar.

Concerning writing materials, there was a significant difference between the two countries, because the classroom in the US had more writing materials and hada rich literacy environment.

\subsection{Writing samples}

The fourth focus of the current study was to describe children's writing development in the two countries. We codedtwenty six writing samples(eleven writing samples in Turkey and fifteen 
writing samples in the US) according to writing via drawing (1), scribbling (2), making letter-like shapes (3), the letters or letter strings (4), and conventional spelling (5).

Table 2. Description Writing Samples

\begin{tabular}{llllll}
\hline $\begin{array}{l}3 \text { Years old in } \\
\text { Turkey } \\
(\mathrm{n}=5)\end{array}$ & $\begin{array}{l}3 \text { Years old } \\
\text { in the US } \\
(\mathrm{n}=3)\end{array}$ & $\begin{array}{l}4 \text { Years old in } \\
\text { Turkey } \\
(\mathrm{n}=4)\end{array}$ & $\begin{array}{l}4 \text { Years old } \\
\text { in the US } \\
(\mathrm{n}=4)\end{array}$ & $\begin{array}{l}5 \text { Years old in } \\
\text { Turkey } \\
(\mathrm{n}=6)\end{array}$ & $\begin{array}{l}5 \text { Years old } \\
\text { in the US } \\
(\mathrm{n}=4)\end{array}$ \\
\hline Cod & Cod & Cod & Cod & Cod & Cod \\
1 & 3 & 1 & 4 & 4 & 5 \\
1 & 4 & 4 & 4 & 4 & 5 \\
1 & 5 & 5 & 4 & 4 & 5 \\
2 & 5 & 5 & 5 & 5 \\
2 & & & & 5 & \\
\hline
\end{tabular}

Looking at Table 2, while the three-year old children were coded at the first $(n=3)$ and second $(n=2)$ levels in Turkey, children were coded at the third $(n=1)$, fourth $(n=1)$, and fifth $(n=1)$ levels in the US. Looking at the writing samples in Turkey, children showed drawing a picture in their writing product. However, children wrote at higher levels in the US, like writing letters. Surprisingly, the four-year old child produced first level writing in Turkey, but others showed four and fifth levels in both countries.

Lastly, the five-year old children usually showed the fifth level, but in Turkey, we coded the fourth level.

\section{Discussion}

Four categories of datawere analized in this study: writing samples, writing materials, writing curriculum, and teachers literacy beliefs. In Turkey the teachers did not think about more supporting literacy with materials and activities, but in the US the teacher explained detail how to support children's literacy with materials and activities. The findings showed that literacy beliefs can be effective in promoting childrens' writing skills. If teachers believe that literacy development in the early years is important, they use rich materials and they have more activity. Justice, Pence, Bowles and Wiggins (2006) examined the factors of learning to identify letters by children. They found that children learn letters with their experiences with letters. As expected, if teachers believe that supporting literacy is important, they provide opportunities for children to develop writing skills, such as using more materials and having a writing center in class (Bennett, Duke, Armstead, \& Moses, 2005).

In this study, the three-years olds' writing sample outcomes showed significant differences for both countries (see Table 1). The three-year old class teacher in Turkey expressed that support is not needed for three-yearold children. On the contrary, in the US the teacher thought that supporting emergent literacy is very important. Looking at the writing samples, the three-yearold children only drew and scribbled in Turkey; however, they made letter shapes, letters, and conventional writing in the US. Four- and five-year old children did not have big 
differences in both countries. Bloodgood (1999) examined children's name writing with their writing samples and she found developmentally that three-yearold children can write their names' first letter and they can identify the number of letters and some letter sounds. Studies have also showed that emergent writing skills improve significantly from three to five-years old (Levin \& Bus, 2003; Puranik \& Lonigan, 2011); however, composing skills, such as writing letters and names and spelling words, increase writing activities and exposure to print (Puranik \& Lonigan, 2011). Puranik and Lonigan (2011) examined children's development of writing; and they found that children show universal features of writing and they begin writing before they are three-yearold, so children can be provided with materials and with use strategies, such as cues, modelling, and feedback, for supporting them. This study showed that teachers' beliefs are effective in children's emergent literacy, because the differentiation of teachers' belief showed parallels with children's writing skills. In support of this view, some research has showed a relationship between teachers' beliefs and young children acquiring early literacy knowledge (Hindman and Wasik 2008; Lynch, 2009). Supporting writing skills in preschool with activities and materials provides meaningful writing, such as letter knowledge or name writing (Mayer, 2007; Riley, 1996; Treiman \& Broderick, 1998).

A few studies have especially showed teacher's literacy beliefs about the role of teachers' programs and their early literacy beliefs. Ure and Raban (2001) examined teachers' literacy beliefs in Australia; they found that teachers' knowledge was limited, and their university education had provided limited literacy development knowledge. Lynch (2009) examined teachers' literacy beliefs in Canada; she found that some preschool teachers believed that kindergarten teachers support for literacy was located in elementary school. Other preschool teachers approached important early educational support with their own activities and goals.

Other related categories are writing activities and using materials. Because the teachers in Turkey planned fewer activities than the US teacher about writing skills, there were very few materials in their classrooms. By contrast, the class in the US had a rich literacy environment and everything in the class had a label; the class also had a writing center and word wall for supporting literacy skills. When children have supportive activities with a literacy environment about meaningful print, children build early literacy concepts and improve their capacity for reading and writing behaviours in preschool (Neuman \& Roskos, 1997; Haney, 2002). Therefore, writing activities and young children's curriculum within a natural context can contribute children's literacy development (Haney, 2002).

There are some study limitations. For instance, this study was conducted with a small group of preschool teachers and children. However, this study showed differences in teachers' beliefs, classroom materials, writing activities, and writing samples for both countries. Further research needs to examine the quality of educational programs and opportunitiesprovidedto explore print. Some practices may occur broadly teachers group and may research interview and observation of preschool teachers together.

\section{References}

Bakst, K., \& Essa, E. L. (1990). The writing table: Emergent writers and editors. Childhood Education, 66(3), 145-150. http://dx.doi.org/10.1080/00094056.1990.10522504 
Bennett, S., Duke, N., Armstead, N., \& Moses, A. (2005). Literacy and the youngestlearner: Best practices for educators of children birth to 5. New York: ScholasticTeaching Resources.

Bloodgood, J. W. (1999). What's in a name? Children's name writing and literacy acquisition. Reading Research Quarterly, 34(3), 342-367. http://dx.doi.org/10.1598/rrq.34.3.5

Buxton, A.E. (2011). Gender differences and writing development in kindergarten. Master of Science: Bechelor of Science in Human Development \& Family Science, Oklahoma University.

Clay, M. M. (1998). By different paths to common outcomes. York, ME: Stenhouse Publishers.

Dickinson, D. K.,\& McCabe, A. (2001). Bringing it all together: Multiple origins, skills and environmental supports of early literacy. Learning Disabilities Research and Practice, 16(4), 186-202. http://dx.doi.org/10.1111/0938-8982.00019

Ferreiro, E.,\& Teberosky, A. (1982). Literacy before schooling. Exeter, NH: Heinemann.

Fleer, M., \& Raban, B. (2006). A cultural-historical analysis of concept formation in early education settings: Conceptual consciousness of the child or only the adult? European Early Childhood Education Research Journal, 14(2), 69-80. http://dx.doi.org/10.1080/13502930285209921

Fogo, J. L. (2008). Writing in preschool.Doctoral dissertation, Purdue University.

Haney, M. R. (2002). Name writing: A window into the emergent literacy skills of young children. Early Childhood Education Journal, 30(2), 101-105. http://dx.doi.org/10.1023/a:1021249218339

Levin, I., Both-De Vries, A., Aram, D., \& Bus, A. (2005). Writing starts with own name writing: From scribbling to conventional spelling in Israeli and Dutch children. Applied Psycholinguistics, 26(03), 463-477. http://dx.doi.org/10.1017/s0142716405050253

Lynch, J. (2009). Preschool teachers' beliefs about children's print literacy development. Early Years: An International Journal of Research and Development, 29(2), 191-203. http://dx.doi.org/10.1080/09575140802628743

Morrow, L. M. (2007). Developing literacy in preschool. USA: Guilford Press.

Neuman, S., Copple, C., \& Bredekamp, S. (2000). Learning to read and write: developmentally appropriate practices for young children. Washington D.C: National Association for the Education of Young Children.

Neuman, S., and K. Roskos. 1997. Literacy knowledge in practice: Contexts for participation for young writers and readers. Reading Research Quarterly, 32, 10-32. http://dx.doi.org/10.1598/rrq.32.1.2

Parker, A.,\& Neuharth, S. (2006). Developmentally appropriate practice in kindergarten: Factors shaping teacher beliefs and practice. Journal of Research in Childhood Education 21(1), 65-78.http://dx.doi.org/10.1080/02568540609594579 
Puranik, C. S., \& Lonigan, C. J. (2011). From scribbles to scrabble: Preschool children's developing knowledge of written language. Reading and writing, 24(5), 567-589. http://dx.doi.org/10.1007/s11145-009-9220-8

Purcell-Gates, V. (1996). Stories, coupons, and the TV guide: Relationships between home literacy and experiences and emergent literacy knowledge. Reading Research Quarterly, 31(4), 406-428. http://dx.doi.org/10.1598/rrq.31.4.4

Riley, J. L. (1996). The ability to label the letters of the alphabet at school entry: ADiscussion on its value. Journal of Research in Reading, 19, 87-101. http://dx.doi.org/10.1111/j.1467-9817.1996.tb00090.x

Schickedanz, J. (1998). What is developmentally appropriate practice in early literacy? Considering the alphabet. In S. Neuman, \& K. Roskos (Eds.), Children achievingbest practices in early literacy (pp. 20-37). Newark, DE: International Reading Association.

Sulzby, E. (1986). Writing and Reading: Signs of oral and written language organizationin the young child.In W. Teale \& E. Sulzby (Eds.) Emergent literacy writing and reading (pp. 50-89). Norwood, New Jersey: Ablex Publishing Corporation.

Treiman, R., \& Broderick, V. (1998). What's in a name? Children's knowledge about theletters in their own names. Journal of Experimental Child Psychology, 70, 97-116. http://dx.doi.org/10.1006/jecp.1998.2448

Ure, C.,\& Raban, B. (2001). Teachers' beliefs and understandings of literacy in the pre-school: Pre-school literacy project stage 1. Contemporary Issues in Early Childhood, 2(2), 157-168. http://dx.doi.org/10.2304/ciec.2001.2.2.3

\section{Appendix}

\section{Interview Questions (Lynch 2009)}

Part I

1. How long have you worked in ECE?

What levels do you teach/work with?

What is your educational background in ECE?

2. Please describe a typical day at the preschool.

3. Has your educational (academic program) preparedyou for your work as a preschool teacher? If so, how(practice)?

4. What would you like to know more about whenworking in/teaching preschool (supporting literacy)?

5. How important is print literacy (reading/writingdevelopment) in preschool?

6. Are there any changes in an ECE preparation programyou would like to see (in literacy)?

Part II (Ure and Raban 2001)

1. What concerns do you have about children's earlyreading and writing?

2. Are there any children in your group(s) that arereading and writing? How do you know this? 
3. What (if any) role do you consider you playin encouraging preschool children to read and towrite?

4. What role (if any) do you consider parents play inencouraging the preschool age children to read and towrite?

5. What curriculum experiences (if any) do you currentlyoffer to foster reading and writing development?

6. At what age should children be encouraged to readand write?

Table 1. Classroom writing materials checklist in the US

\begin{tabular}{|c|c|c|c|c|c|c|}
\hline \multicolumn{7}{|l|}{ Print materials } \\
\hline & exists & absent & exists & absent & exists & absent \\
\hline Are print materials put in a child's eye level? & $\mathrm{x}$ & & $\mathrm{x}$ & & $\mathrm{x}$ & \\
\hline Is there a calendar? & $\mathrm{x}$ & & $\mathrm{x}$ & & $\mathrm{x}$ & \\
\hline Is there a weather chart? & $\mathrm{x}$ & & $\mathrm{x}$ & & $\mathrm{x}$ & \\
\hline Is there a daily schedule? & $\mathrm{x}$ & & $\mathrm{x}$ & & $\mathrm{x}$ & \\
\hline Is there an alphabet poster? & $\mathrm{x}$ & & $\mathrm{x}$ & & $\mathrm{x}$ & \\
\hline Are children's book exhibited or are there? & $\mathrm{x}$ & & $\mathrm{x}$ & & & $\mathrm{x}$ \\
\hline Is there a name card? & $\mathrm{x}$ & & $\mathrm{x}$ & & & $\mathrm{x}$ \\
\hline Are there any magnetic letters? & $\mathrm{x}$ & & $\mathrm{x}$ & & & $\mathrm{x}$ \\
\hline Are learning centers' names written? & $\mathrm{x}$ & & $\mathrm{x}$ & & & $\mathrm{x}$ \\
\hline Are children's names written on the wall & $\mathrm{x}$ & & $\mathrm{x}$ & & & $\mathrm{x}$ \\
\hline Writing Materials & $\mathrm{x}$ & & $\mathrm{x}$ & & & $\mathrm{x}$ \\
\hline $\begin{array}{l}\text { Are there any writing materials in the } \\
\text { learning centers? }\end{array}$ & $\mathrm{x}$ & & $\mathrm{x}$ & & & $\mathrm{x}$ \\
\hline Is there a writing center? & $\mathrm{x}$ & & $\mathrm{x}$ & & & $\mathrm{x}$ \\
\hline Are there any different properties papers? & $\mathrm{x}$ & & $\mathrm{x}$ & & & $\mathrm{x}$ \\
\hline Are there any diffrent properties pencils? & $\mathrm{x}$ & & $\mathrm{x}$ & & & $\mathrm{x}$ \\
\hline Is there a writing board? & $\mathrm{x}$ & & $\mathrm{x}$ & & & $\mathrm{x}$ \\
\hline Are there any letter patterns? & $\mathrm{x}$ & & $\mathrm{x}$ & & & $\mathrm{x}$ \\
\hline
\end{tabular}


Table 2. Classroom writing materials checklist in Turkey

\begin{tabular}{|c|c|c|c|c|c|c|}
\hline \multicolumn{7}{|l|}{ Print materials } \\
\hline & exists & absent & exists & absent & exists & absent \\
\hline $\begin{array}{l}\text { Are print materials hold at a child's eye } \\
\text { level? }\end{array}$ & $\mathrm{x}$ & & $\mathrm{x}$ & & & $\mathrm{x}$ \\
\hline Is there a calendar? & $\mathrm{x}$ & & $\mathrm{x}$ & & & $\mathrm{x}$ \\
\hline Is there a weather chart? & $\mathrm{x}$ & & $\mathrm{x}$ & & & $\mathrm{x}$ \\
\hline Is there a daily schedule? & & $\mathrm{x}$ & & $\mathrm{x}$ & & $\mathrm{x}$ \\
\hline Is there an alphabet poster? & & $\mathrm{x}$ & & $\mathrm{x}$ & & $\mathrm{x}$ \\
\hline Are children's book exhibited? & & $\mathrm{x}$ & & $\mathrm{x}$ & & $\mathrm{x}$ \\
\hline Are there any name cards? & & $\mathrm{x}$ & & $\mathrm{x}$ & & $\mathrm{x}$ \\
\hline Is there a magnetic letters? & & $\mathrm{x}$ & & $\mathrm{x}$ & & $\mathrm{x}$ \\
\hline Are learning centers' names written? & & $\mathrm{x}$ & $\mathrm{x}$ & & & $\mathrm{x}$ \\
\hline Are children's names written on the ? & & $\mathrm{x}$ & $\mathrm{x}$ & & & $\mathrm{x}$ \\
\hline Writing Materials & & & & & & $\mathrm{x}$ \\
\hline $\begin{array}{l}\text { Are there any writing materials in the } \\
\text { learning centers? }\end{array}$ & $\mathrm{x}$ & & & $x$ & & $\mathrm{x}$ \\
\hline Is there a writing center? & & $\mathrm{x}$ & & $\mathrm{x}$ & & $\mathrm{x}$ \\
\hline Are there any different properties papers? & $\mathrm{x}$ & & $\mathrm{x}$ & & & $\mathrm{x}$ \\
\hline Are there any diffrent properties pencils? & $\mathrm{x}$ & & $\mathrm{x}$ & & & $\mathrm{x}$ \\
\hline Is there a writing board? & $\mathrm{x}$ & & $\mathrm{x}$ & & & $\mathrm{x}$ \\
\hline Are there any letter patterns? & & $\mathrm{x}$ & & $\mathrm{x}$ & & $\mathrm{x}$ \\
\hline
\end{tabular}

